\title{
An overview of the ongoing insights in selenium research and its role in fish nutrition and fish health
}

\author{
Kifayat Ullah Khan $(\mathbb{D} \cdot$ Amina Zuberi • \\ João Batista Kochenborger Fernandes • Imdad Ullah • \\ Huda Sarwar
}

Received: 21 February 2017 / Accepted: 26 June 2017 / Published online: 15 July 2017

(C) Springer Science+Business Media B.V. 2017

\begin{abstract}
In the present review, the ongoing researches about selenium research in fish nutrition have been comprehensively discussed. Selenium research is getting popularity in fish nutrition as it is required for the normal growth and proper physiological and biochemical functions in fish. Its deficiency or surplus amounts create severe problems in fish. It is available as inorganic form, organic form, and nano form. In fish, most of the previous research is about the selenium requirements for fish by using only one selenium source mainly the inorganic one. Selenium shows maximum biological activity and bioavailability when it is supplied in proper form. However, to differentiate the more bioavailable and less toxic form of selenium, sufficient information is needed about the comparative bioavailability of different selenium forms in different fish species. In fish, important data about the new forms of selenoproteins is still scarce. Therefore, it is necessary to focus on the determination and elucidation of the new selenoproteins in fish through the utilization of recent approaches of molecular biology and proteomics. The adaptation of these new approaches will replace the old fashioned methodologies regarding the selenium research in fish nutrition. Moreover, the use of molecular biology and
\end{abstract}

K. U. Khan $(\varangle) \cdot$ J. B. K. Fernandes

Center of Aquaculture, São Paulo State University, Jaboticabal, SP, Brazil

e-mail: Kifayat055@gmail.com

K. U. Khan · A. Zuberi · I. Ullah · H. Sarwar Department of Animal Sciences, Quaid-i-Azam University, Islamabad, Pakistan proteomics-based new approaches in combination with selenium research will help in optimizing the area of fish nutrition and will improve the feed intake, growth performance, and more importantly the flesh quality which has a promising importance in the consumer market.

Keywords Fish $\cdot$ Micronutrients research $\cdot$ Health consequences

\section{Introduction}

Selenium is an important micronutrient and being a strong antioxidant when it is supplied in fish diets considerably improves its health. It helps in protecting fish body cells and cellular components from the oxidative damage through the activation of selenoenzymes and selenoprotein (Rotruck et al. 1973; Watanabe et al. 1997; Hsu and Guo 2002; Sarada et al. 2002; Chien et al. 2003; Hamilton 2004; Zuberbuehler et al. 2006; Raza 2012; Jamil 2013; Khan et al. 2016). In wild aquatic environment, fish usually gets selenium from the surrounding available sources while in very intensive fish culture systems, it depends on the intake of proper feed ingredients which are enriched with proper selenium amounts. The use of animal- (which contains little amount of selenium) and plant-based ingredients (which possess great variability in their selenium content) in fish feeds disturb the proper selenium supply. Any such disturbance in selenium supply results in its impaired antioxidant activity, due to which the fish does not remain capable to fight well against stressful 
conditions and protect itself from the oxidative damage (Tanguy et al. 1998; Toufektsian et al. 2000; Raza 2012; Jamil 2013; Khan et al. 2016). Therefore, while taking into consideration all such factors, the supplementation of a proper amount of dietary selenium in the fish diets is needed for the balanced hormone production and metabolism, and the synthesis and regulation of selenoproteins, improvement of the antioxidant defense status, and more importantly the flesh quality of fish (Pappas and Zoidis 2012; Raza 2012; Jamil 2013; Khan et al. 2016).

In fish nutrition, the effectiveness of a nutrient/ supplement depends mainly on its bioavailability. Role of selenium in the promotion of fish health is not only dependent on its amount of Se intake but also on the transformation of absorbed selenium to metabolically more active forms (Raza 2012; Jamil 2013; Khan et al. 2016). Mainly selenium is available in the environment in two forms such as inorganic form and organic form (Arteel and Sies 2001). However, recently nano form selenium (Zang et al. 2001; Zhou et al. 2009; Jamil 2013; Khan et al. 2016) has been developed and introduced recently into fish feed.

In earlier researches, it has been revealed that organic forms of selenium are usually more bioavailable and have more profound benefits in fish as compared to the inorganic forms (Wang and Lovell 1997; Mahan 1999). However, selenium bioavailability is difficult to enumerate due to the complication of feed ingredients (Fairweather-Tait et al. 2010). Some researchers have worked on to differentiate the more bioavailable form of selenium in fish. According to Raza (2012), sodium selenite supplementation in Tor putitora shows better effects on fish growth and biochemical health. The dietary selenium absorption in the form of selenite in rainbow trout (Salmo gairdneri Richardson) gut has been described to be very effective, though the removal of selenium by the liver tissue may be controlled by a metabolic conversion of selenium to a form that can be evacuated (Hilton et al. 1980). Generally, organic form of selenium such as selenomethionine possesses greater absorption and more bioavailability in fathead minnows (Pimephales promelas Rafinesque) (Kleinow and Brooks 1986). The foodstuffs that contain sufficient amount of organic selenium such as selenomethionine are good sources of Se supply to fish (WHO 1987; Reilly 2006; Rayman 2012). In the diets of channel catfish (Wang and Lovell 1997) and Atlantic salmon (Bell and Cowey 1989; Lorentzen et al. 1994) when organic sources of selenium were added, greater bioavailability was observed than the inorganic source supplementation. Kucubaby et al. (2009) documented that rainbow trout (Oncorhynchus mykiss) fed diets supplemented with the organic selenium showed better absorption and more bioavailability as compared to the diet supplemented with the inorganic selenium.

In fish, usually the organic sources of selenium have been determined to have more bioavailability and possess better health impacts than the inorganic sources (Wang and Lovell 1997; Reilly 2006; Rayman 2012). However, to know which form is more bioavailable can also be contingent with the under study desired parameter because only growth performance data are not sufficient for recommending an optimum selenium level for a fish species. Parallel to growth and feeding parameters, physiological, biochemical, and molecular level (such as the expression of selenoproteins) parameters also play a key role in finding an optimum selenium level for a fish species. The details behind the reason that why organic selenium is more bioavailable than the inorganic selenium is that unlike the selenite, selenomethionine more efficiently integrates into fish tissues (Lorentzen et al. 1994; Wang and Lovell 1997; Cotter et al. 2008; Rider et al. 2008). In a previous study about the effects of organic selenium on glutathione peroxidase activity, it was observed that dietary organic selenium supplementation more beneficently improved the glutathione peroxidase activity in common carp (Cyprinus carpio) (Jovanovic et al. 1997) and catfish (Ictalurus punctatus) (Wang and Lovell 1997). However, in rainbow trout (Rider et al. 2008), Atlantic salmon (Salmo salar) (Bell and Cowey 1989), and hybrid striped bass (Morone chrysops $\times$ M. saxatilis) (Cotter et al. 2008), any profound effects were not observed with the supplementation of dietary organic selenium. Comparatively, little is known about the selenium impact on the fish immune system (Lall 2000); however, studies in catfish have shown that organic selenium is more potent in restoring immunity and the supplementation of sub-optimal dietary selenium decreases the disease resistance in fish (Wang et al. 1997). In a study conducted with $T$. putitora, Khan et al. (2016) observed that the selenium nanoparticles supplementation positively enhanced the innate immunity by improving the serum lysozyme activity and glutathione peroxidase activities in the liver and muscle tissues. Feed ingredients which are commonly used in fish nutrition contain organic selenium such as 
selenomethionine (Schrauzer 2006) which is an important selenoprotein (Surai 2006). Organic sources can provide selenium as the naturally occurring form. This form of selenium is non-redoxing, non-catalytic, shows less toxicity as well as also integrates easily into fish tissues in the forms of selenoproteins as compared to the inorganic form (Sphallholz 1997; Stewart et al. 1999; Schrauzer 2003).

Materials at the nano-scale have been proven to show unique effects as compared to the bulk form (Albrecht et al. 2006). The fast development of nanotechnology is showing great potential for using small size nanoparticles of trace elements (e.g., selenium) in fish feeds. However, nanotechnology is a new area, yet not explored well, special precautions are needed before introducing nanoparticles into fish feeds on large scale. Some studies are available about the effects of dietary selenium nanoparticles in fish which shows that nano selenium is more bioavailable and possess minor toxicities in fish as compared to the organic and inorganic forms of selenium (Zhang et al. 2008; Jamil 2013). The supplementation of selenium nanoparticles has been studied in fish and showed positive impact on its health (Zhang et al. 2001; Zhou et al. 2009; Jamil 2013; Khan et al. 2016). However, in some other animals such as mice and rats (Zhang et al. 2005, 2008; Wang et al. 2007), it has been reported that nano form of selenium owns comparable efficiency to inorganic and organic forms in improving the activity of selenoenzymes.

As the information about the use of selenium nanoparticles in fish feed is not enough to conclude clearly that which form of selenium is more bioavailable in fish. Li et al. (2008) have conducted an experiment with Medaka (Oryzias latipes) and noted that the dietary supplementation of nano form of selenium causes better protective influences during stressful conditions, which may be due to the hyper-accumulation of selenium in liver; however, they also reported that the same dose showed more toxicity than sodium selenite in some other health aspects. This shows that selenium bioavailability and effectiveness depends on a number of biological factors. Thus, it is necessary to conduct some comparative comprehensive studies about different Se forms in different fish species by evaluating maximum number of biological health aspects. These kinds of studies will help in getting a clear knowledge about the absorption, distribution, and approval of different selenium forms and levels. Once such information is obtained, then it becomes easy to define the selenium integration proficiencies and elimination proportions, which in consequence are useful to estimate the longterm and steady-state tissue selenium levels for different fish species (Baines et al. 2002; Li et al. 2008).

\section{Selenium requirements}

Different fish species require specific amount of selenium for the maintenance of its normal growth and health status (Wang et al. 1997; Janz et al. 2010; Raza 2012; Jamil 2013; Khan et al. 2016). The quantity of selenium required for a fish species depends on the form of selenium such as organic, inorganic, and nano form (Burk 1976; Sunde 1984; Mateo et al. 2007; Juniper et al. 2008; Vignola et al. 2008; Janz et al. 2010; Janz 2011; Jamil 2013), fish health condition, fish size, fish species, diet formulation, experiment condition, and water quality (Zhu et al. 2011). The selenium requirements for different fish species have been mentioned in (Table 1).

\section{Selenium deficiency and its surplus amounts}

Fish can maintain its proper growth and strong antioxidant status when it receives sufficient amount of selenium in its diet (Raza 2012; Jamil 2013; Khan et al. 2016); however, its complete absence or deficiency in fish feed results in growth depression and immune instabilities (Lin and Shiau 2005; Cotter et al. 2008). Poston et al. (1976) reported that mortality occurs in salmon fry when it consumes selenium-deficient diets which can be stopped by the supplementation of a $0.1 \mathrm{mg} \mathrm{Se} \mathrm{kg}{ }^{-1}$. When Atlantic salmon fed a seleniumdeficient diet for 26 weeks, the insufficiency symptoms such as laziness, appetite loss, less muscle quality, and high mortality rates were observed. However, the best growth was achieved by the supplementation of a $0.15 \mathrm{mg} \mathrm{Se} \mathrm{kg}{ }^{-1}$ diet (Poston and Combs 1979). Selenium-deficient salmon showed susceptibility to the Vibrio pathogen (Hitra disease) (Fjoelstad and Heyeraas 1985; Poppe et al. 1986). Apart from muscular dystrophy and myocardial erosion, this disease can be diagnosed by the appearance of anemia, hemorrhages, and fluid in the peritoneal cavity and in the pericardium part. Thorough researches on Atlantic salmon by Bell et al. (1987) have described selenium as the main 
Table 1 Selenium requirements for different fish species

\begin{tabular}{lll}
\hline Fish species & Se requirements $\left(\mathrm{mg} \mathrm{kg}^{-1}\right)$ & References \\
\hline Mahseer (Tor putitora) & 1.5 & Raza (2012) \\
Mahseer (Tor putitora) & 0.68 & Jamil (2013); Khan et al. (2016) \\
Rainbow trout (Oncorhynchus mykiss) & $0.15-0.38$ & Hilton et al. (1980) \\
Channel catfish (Ictalurus punctatus) & 0.25 & Gatlin and Wilson (1984) \\
Juvenile grouper (Epinephelus malabaricus) & 0.7 & Lin and Shiau (2005) \\
Cobia (Rachycentron canadum L.) & $0.788-0.811$ & Liu et al. (2010) \\
Gibel carp (Carassius auratus) & 1.18 & Han et al. (2011) \\
Largemouth bass (Micropterus salmoides) & $1.60-1.85$ & Zhu et al. (2012) \\
African catfish (Clarias gariepinus B.) & 300 & Abdel-Tawwab et al. (2007) \\
Marron (Cherax cainii) (Austin, 2002) & 0.4 & Nugroho and Fotedar (2013) \\
Tilapia (Oreochromis niloticus) & 1.5 and 6.0 & Atencio et al. (2009) \\
Matrinxã (Brycon cephalus) Günther (1869) & 1.5 & Monteiro et al. (2009) \\
Rainbow trout (Oncorhynchus mykiss) & $500-4000$ & Pacitti et al. (2015) \\
Common carp (Cyprinus carpio L) & 0.12 and 0.15 & Gaber (2007) \\
On-growing gibel carp (Carassius auratus gibelio var. CAS III) & $0.73,1.12$, and 1.19 & Zhu et al. (2016) \\
Juvenile grouper (Epinephelus malabaricus) & 0.90 and 0.98 & Lin (2014) \\
Yellowtail kingfish (Seriola lalandi) & 5.56 & Le et al. (2013) \\
\hline
\end{tabular}

element in the defensive mechanism against oxidative stress.

Additionally, the absence or low selenium levels in fish feeds also result in reduced tissue Se concentrations, low hematocrit values, and increased hemolytic rates (Jamil 2013; Khan et al. 2016). Its low levels causes improper enlargements in the endoplasmic reticulum of the pancreatic tissue and the area of vacuolation and decline the glutathione peroxidase activity in liver tissue while improve the glutathione transferase and pyruvate kinase activities (Poston and Combs 1979; Fjoelstad and Heyeraas 1985; Poppe et al. 1986; Bell et al. 1987; Khan et al. 2016). A decrease in plasma glutathione peroxidase activity in rainbow trout occurs when fed a selenium-deficient diet (Hilton et al. 1980) while its absence in T. putitora feed resulted in a decreased glutathione peroxidase activity in the liver and muscle tissues (Khan et al. 2016). Bell et al. (1985) stated that selenium deficiency causes the reduced glutathione peroxidase activity in the rainbow trout liver. According to the findings of Gatlin and Wilson (1984), inadequate supply of selenium causes lower growth and a decreased glutathione peroxidase activity in channel catfish. The deficiency signs in channel catfish in response to lower levels of selenium can be noticed through the reduced glutathione peroxidase and glutathione transferase activities (Gatlin et al. 1986). Hicks et al. (1984) have identified the nephrocalcinosis disease in rainbow trout in response to the consumption of a selenium-deficient diet. During this disease, the renal tubules degenerate which then lead to infection and consequently weakens the fish immunity status.

The selenium deficiency signs reported to be a major cause of the dissolution of liver cell membranes and the compressed nuclei, due to which pathological alterations occur in nerve cells, as a result the blood cells become reduced which cause anemia (Bell et al. 1986) as well as also impair the deiodinase and glutathione peroxidase activities in fish (Beckett et al. 1993; Meinhold et al. 1993; Brigelius-Flohe 1999; Arteel and Sies 2001; Jamil 2013; Khan et al. 2016). In salmonids, selenium scarcities led to ataxia, muscular dystrophy, lipid peroxidation, and decreased plasma and hepatic glutathione peroxidase activity (Poston et al. 1976; Hodson and Hilton 1983; Bell et al. 1985; Bell et al. 1986; Bell et al. 1987). Bell et al. (1987) indicated that selenium deficiency in fish results in a reduced growth, less packed cell volume, loss of reliability in the 
endoplasmic reticulum, increased vacuolation, and a reduced glutathione peroxidase activity in the liver tissue, increased hepatic glutathione S-transferase activity, increased plasma pyruvate kinase activity, and an increased erythrocyte delicacy in fish.

Selenium is essential for the maintenance of fish health (Klasing 1998; Patching and Gardiner 1999; Eisler 2000; Raza 2012; Jamil 2013; Khan et al. 2016). However, positive or negative changes in the fish health appear to be closely associated to the internal selenium amounts. When selenium concentrations in the body exceed the optimum level and start to accumulate in higher quantity in various fish tissues such as the muscle, liver, and kidney tissues, then exerts negative impact on the health of fish and cause toxicities (Hilton et al. 1980; Raza 2012; Jamil 2013; Rodríguez and Rojas 2014).

Selenium toxicity occurs because of the association of selenium with sulfur-containing amino acids due to which the proper functional enzyme system disturbs (Diplock 1976). Various studies have been documented that selenium-based toxicity can lead to digestive abnormalities, neurologic manifestations including acroparesthesias, weakness, convulsions, and decreased cognitive function, as well as it also negatively affect the defense system of fish (Clark et al. 1996; Gasmi et al. 1997; Raza 2012). After the overview of the available researches on selenium toxicity, information about the comparative toxicity of different selenium forms during normal conditions and the way different selenium forms act at the cellular and molecular levels is still unclear in fish. Thus, it is necessary to focus on differentiating the selenium levels to be supplemented in fish feed during the stressful conditions and during the normal state to remove the major fluctuations in selenium levels. Secondly, the molecular level impacts of different selenium forms in fish should be focused and addressed well. These determinations will help to reduce the supplementation of surplus amounts of selenium in fish feed during the normal conditions which may be a source of increasing costs and toxicities and more importantly will explore considerably the negative role of excess selenium in causing genetic toxicity in fish.

Selenium toxicity not only depends on the chemical form of selenium and body liability but also on a variety of other factors such as the physiological state, dietary interactions, and route of supplementation (Zhang et al. 2001; Zhang et al. 2005; Albrecht et al. 2006; Wang et al. 2007; Zhang et al. 2008; Jamil 2013; Khan et al.
2016). The existing research data describe that fish is susceptible to the dietary selenium toxicity of 4600

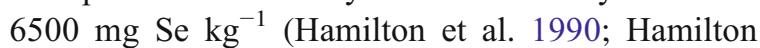
2003). In rainbow trout, selenite is chronically toxic at the level of $10 \mathrm{mg} \mathrm{Se} \mathrm{kg}^{-1}$ (Hodson and Hilton 1983). However, in Chinook salmon, the selenomethionine supplementation does not show any toxicity signs even up to the level of $18 \mathrm{mg} \mathrm{Se} \mathrm{kg}^{-1}$ (Hamilton et al. 1990).

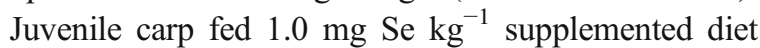
showed higher accumulation in the liver and kidney tissues; however, in the muscle tissue, no such higher deposition was observed. Despite the fact that high selenium-supplemented diet showed oxidative stress in the liver and kidney tissues in terms of increased biomarker activities, the authors concluded that the high selenium level, i.e., $1.0 \mathrm{mg} \mathrm{Se} \mathrm{kg}{ }^{-1}$ is optimum for juvenile carp (Elia et al. 2011). The reason behind the conclusion of such a high selenium level explained by the authors was that as muscle is the edible part of fish which showed less selenium deposition, thus good for human consumption (Elia et al. 2011). But this type of philosophy is incorrect, unscientific, and unacceptable in fish nutrition because selenium research in fish is necessary to consider the optimum selenium level for a species on the basis of its optimum growth, and physiological and biochemical responses without causing higher deposition which later on may become a source of any stress. In prawn, the supplementation of dietary selenium at the rate of $1.25 \mathrm{mg} \mathrm{kg}^{-1}$ shows toxicity and produces adverse effects in its health (Wang et al. 1994). Besides fish, the inconsistency between the toxicity of different forms of selenium has also been found in terrestrial animals such as poultry (Todorovic et al. 2004).

Selenium supplementation at the rate of $13 \mathrm{mg}$ $\mathrm{Se} \mathrm{kg}^{-1}$ dry feed causes prolonged dietary selenium toxicity in rainbow trout, decreased growth, deprived feed conversion efficiency, and high mortality (Hilton et al. 1980). In channel catfish, toxicity was detected with the supplementation of $15 \mathrm{mg} \mathrm{Se} \mathrm{kg}{ }^{-1}$ diet causing reduced growth and decreased feed conversion efficiency (Gatlin and Wilson 1984). Hicks et al. (1984) reported that rainbow trout fed $11.4 \mathrm{mg} \mathrm{Se} \mathrm{kg}^{-1}$ showed reduced weight, reduced feed conversion efficiency, high mortality, and about $90 \%$ of fish also suffered from nephrocalcinosis disease. Hilton and Hodson (1983) observed renal calcinosis, decreased growth, and less feed conversion efficiency in rainbow trout raised on diets containing high selenium (10 $\mathrm{mg} \mathrm{Se} \mathrm{kg}^{-1}$ ). 
Mortality increased in Chinook salmon when subjected to about $9.6 \mathrm{mg} \mathrm{Se} \mathrm{kg}^{-1}$ by using two organic sources such as high selenium fish meal and selenomethionine (Hamilton et al. 1990). Moreover, growth was reduced when Chinook salmon fed on about 5.3 and $18.2 \mathrm{mg} \mathrm{Se} \mathrm{kg}^{-1}$, as obtained from fish meal and selenomethionine, respectively.

Major advantage of organic selenium over the inorganic selenium is that the difference between the toxicity and nutritionally optimum levels are minor for inorganic selenium. This means that inorganic selenium levels that may be advantageous and optimum for a fish species during stressful conditions may be near to those of toxic in normal conditions (Felton et al. 1989; Sandstrom 2001). This narrow difference between the optimum and toxic selenium levels may be due to the difference in the selenium absorption rate in the intestine which is an important feature of homeostasis (Underwood 1977). Fish show low retention either due to the unnecessary consumption or lower intake of selenium and this problem can be overcome by the supplementation of optimum dietary levels and using sources with higher bioavailability. Hilton et al. (1980) and Hilton and Hodson (1983) reported that selenium toxicity range in rainbow trout (Oncorhynchus mykiss) is $13-15 \mathrm{mg} \mathrm{Se} \mathrm{kg}^{-1}$. Fathead minnow (Pimephales promelas) fed diets containing a mixture of inorganic and organic selenium levels as 0.5 to $160 \mathrm{mg} \mathrm{Se} \mathrm{kg}{ }^{-1}$ diet showed depressed growth at the levels of 20 and $30 \mathrm{mg} \mathrm{Se} \mathrm{kg}^{-1}$ (Ogle and Knight 1989). Teh et al. (2004) observed that prolonged subjection of juvenile splittail (Pogonichthys macrolepidotus) to $6.6 \mathrm{mg} \mathrm{Se} \mathrm{kg}{ }^{-1}$ diet persuades harmful health impact which can possibly also affect its survival. A recent study conducted by Tashjian et al. (2006) showed that white sturgeon (Acipenser transmontanus) is relatively less sensitive to selenium toxicity as compared to other fish species and reported a dietary selenium toxicity level of $10 \mathrm{mg}$ Se $\mathrm{kg}^{-1}$ diet for the sturgeon fish.

Lemly (1997) and Janz et al. (2010) reported that the subjection of adult fish to dietary selenomethionine causes developmental abnormalities and mortalities in F1 larval fish. In adult female fish, selenomethionine is stored into eggs during vitellogenesis process and the successive use of selenomethionine in yolk by developing embryos is the main cause of deformities and mortality. Also, the introduction of juvenile fish to dietary selenomethionine has been described to weaken the physiological responses to stressors and thus reduces the endocrine functions (Teh et al. 2004; Wiseman et al. 2011a, b). A general discussion among the aquatic toxicologists is that adult fish are accepting chronic exposure of selenomethionine while acute toxicity of selenium to adult fish has been examined at levels that are not biologically appropriate. However, less information exist on the chronic selenium toxicity in the adult fish. An earlier investigation confirmed that exposure of adult zebrafish (Danio rerio) to dietary selenomethionine causes depressed swimming ability and accumulation of deposited energy, and results in higher production of cortisol hormone (Thomas and Janz 2011).

Naturally, acute selenium intoxication is scarce as animals are not usually subjected to high selenium intake because they have a tendency to evade intake of selenium contained plants. The distinctive indications of selenium toxicity can be distinguished by the production of garlic like odor and pathological alterations that occur in various tissues of fish body (Levander 1986; WHO 1987, 1996) and it causes severe tissue pathology and reproductive failure in fish (Lemly 2002; Sorensen 1986). The surpass quantities of selenium causing incorrect replacement for sulfur and causing the development of a triselenium bond or a selenotrisulfide bond, both of which stop the formation of the essential disulfide chemical linkages. Then, a distortion occurs in the normal functioning of the selenoenzymes which lead to the inactivation of selenoproteins and consequently, the cellular and biochemical health status of fish declines (Ganther, 1978; Diplock 1976; Reddy and Massaro 1983; Sunde 1984).

Selenium toxicity-based alterations in the aquatic environment can have numerous negative effects in fish as observed in the Belews Lake, North Carolina, USA. The lack was contaminated by selenium which was added to the lake from a coal-fired power plant and produced various toxic influences in fish. Signs related to long-lasting selenium toxicity observed in the fishes of Belews Lake included swelling of gill lamellae; raised white blood cells; decreased hematocrit and hemoglobin; corneal cataracts; exopthalmus; pathological changes in liver, kidney, heart, and ovary; reproductive failure; and teratogenic abnormalities of the spine, head, mouth, and fins (Lemly 2002). Due to the sever selenium toxicity, several fish species were removed from the Lake.

\section{Growth performance of fish}

Selenium supplementation in fish feed increases the performances of fish through the stimulation of serum 
growth hormone production (Raza 2012; Khan et al. 2016, 2017). The mechanism behind the role of selenium in growth hormone stimulation and regulation is that selenium is an integral part of the deiodinase enzyme, an important enzyme which is required for the proper regulation of the thyroid hormone (Kohrle et al. 2000; Kohrle and Gartner 2009). Thyroid hormones are essential for the stimulation and appropriate secretion of growth hormone from the pituitary gland in fish and other vertebrates (Valcavi et al. 1992; Muller et al. 1999; Jamil 2013; Khan et al. 2016). The active form of thyroid hormone is $\mathrm{T}_{3}$ which raises the growth hormone messenger RNA levels in the pituitary cells of fish (Moav and McKeown 1992; Farchi-Pisanty et al. 1995). Artificial thyroxin injection is also capable of stimulating the active bA production in the rising tissues of female Oreochromis niloticus larvae (Mousa 2004). Likewise, treatment of young rainbow trout (Oncorhynchus mykiss) with $\mathrm{T}_{3}$ hormone for a period of 1 week increases the growth hormone mRNA levels in the pituitary gland cells about three to four times higher as compared to the control fishes which do not receive the $T_{3}$ hormone (Moav and McKeown 1992). Besides fish, in other animals such as rats, the supplementation of selenium also considerably improves the stimulation and secretion of growth hormone (Ewan 1976).

The serum growth hormone levels increased significantly in T. putitora in response to the 3-month supplementation of dietary inorganic selenium in its feed (Raza 2012). Similarly, in another study, same fish species that received the selenium nanoparticle-containing diet for a period of 70 days showed significantly higher serum growth hormone levels as compared to the control fish which did not receive any selenium nanoparticles (Khan et al. 2016). According to the previous literature, a close relationship exists between the serum growth hormone level, growth performance, and selenium intake. The fish showed significantly higher serum growth hormone levels and gained considerably higher growth performance (Collipp et al. 1984; Raza 2012; Khan et al. 2016).

Dietary Se supplementation improves the growth and feeding parameters in fish (Hilton et al. 1980; Bell et al. 1985; Lin and Shiau 2005; Raza 2012; Jamil 2013; Khan et al. 2016). The weight gain and feed efficiency of juvenile grouper significantly increased when fed selenium-supplemented diet as compared to seleniumfree diet (Lin and Shiau 2005). African catfish when fed organic selenium showed considerably higher growth performance and feeding efficiency (Abdel-Tawwab et al. 2007). Intake of dietary iodine and seleniumsupplemented rotifers increased $32 \%$ the survival rate in Cod larvae (Hamre et al. 2008). Nugroho and Fotedar (2013) documented that marron (Cherax cainii) (Austin 2002) fed selenium-supplemented diet for 90 days showed significantly improved weight gain, specific growth rate, and survival rate. In another study conducted by Lin (2014), the supplementation of selenomethionine in grouper fish diet caused a higher weight gain and higher muscle water retention.

The weight gain percentage results of grouper fish reported by Lin (2014) relates positively with the values reported by Lin and Shiau $(2003,2005)$ and in which 200-300 WG\% was observed in similar size groupers fed diets containing nutritionally sufficient selenium for a period of about 8 weeks. Several previous authors have reported that selenium supplementation in fish feed not only increases fish weight gain but also improves its meat quality (Mahan and Parrett 1996; Mahan et al. 1999; Juniper et al. 2008) by decreasing the oxidative stress in flesh. Lin (2014) demonstrated that dietary selenium supplementation improves the meat quality and water-holding capacity of muscle in groupers. Fingerling and juvenile carp showed significant improvement in its weight gain and survival rate when consumed a diet supplemented with Se (Gaber 2007). A 6-week supplementation of dietary selenium had no effect on the survival rate in yellowtail kingfish; however, after the bacterial challenge test, the selenium intake revealed its immune promoting effects and improved the survival rate in yellowtail kingfish (Le et al. 2013). Wang and Lovell (1997) observed that the channel catfish (Icthalurus punctatus) fed a basal diet (without selenium) showed low weight gain and a poor feed efficiency. The supplementation of Se diet improves the growth performance and antioxidant activities (glutathione peroxidase and glutathione reductase) while reduces the oxidative stress in the flesh of matrinxã (Brycon cephalus) (Monteiro et al. 2007).

In a study conducted with two groups of adult Atlantic salmon (Salmo salar) in sea cages, it was observed that fish fed diet based on fish silage containing Se showed no considerable impact on growth, feed conversion ratio, and protein efficiency ratio in Atlantic salmon (Julshamn et al. 1990). According to Kucubaby et al. (2009), addition of any level of selenium to practical diets or source of selenium did not show any 
important influence on the growth gain in rainbow trout kept at low density $\left(25 \mathrm{~kg} \mathrm{~m}^{-3}\right)$. However, the same species when kept under high density $\left(100 \mathrm{~kg} \mathrm{~m}^{-3}\right)$, the supplementation of selenium improved its feed intake, body weight, and feed conversion ratio. Furthermore, fish presented better results on the consumption of organic selenium as compared to the inorganic form showing that the organic form possesses better intestinal absorption capacity than the inorganic form. Zhu et al. (2016) reported that supplementation of dietary selenium levels did not significantly affect the thermal growth coefficient and feed efficiency in fish; however, the condition factor of the fish was decreased with dietary selenium supplementation.

Dietary selenium can affect the hepatosomatic index in fish (Cotter et al. 2008; Liu et al. 2012; Zhu et al. 2012); however, no significant difference was observed in hepatosomatic index in a previous study conducted by Zhu et al. (2016). In some other fish species, such as rainbow trout and juvenile gibel carp, the selenium supplementation did not give better results in terms of hepatosomatic index (Hilton et al. 1980; Han et al. 2011). Atlantic salmon parr (Salmo salar) fed basal diet (either unsupplemented or supplemented with low selenium levels (as selenite or selenomethionine, respectively)) for a period of 8 weeks showed no prominent effects on its weight gains (Lorentzen et al. 1994). In T. putitora, the supplementation of selenium nanoparticles positively affected the hepatosomatic index indicating the good health condition of fish after the selenium nanoparticles supplementation.

\section{Physio-biochemical health of fish}

Fish is living in aquatic environments; its physiobiochemical health serves as an important indicator of the environment. Even a little alteration in the physiobiochemical health status alarms fish to protect its body from any surrounding danger. However, when the physio-biochemical health operates well and within the optimum range, it signifies that the environment is favorable and stress free. The physio-biochemical health of fish is comprise of hematological, immunological, and biochemical systems.

Proper selenium supplementation through the regulation of the innate immunity and antioxidant defense status conserves the optimum health parameters of fish (Rayman 2000; Brown and Arthur 2001; Raza 2012;
Jamil 2013; Khan et al. 2016). Selenium levels in body tissues of cultivated salmonids are considerably less than their wild counterparts (Poppe et al. 1985; Felton et al., 1996; Julshamn et al. 1990). This inconsistency may be due to a number of factors such as differences in the growth rates and feeding systems (Maage et al. 1991), low dietary selenium digestibility in cultured fish diets compared to natural prey, and selenium losses resulting from stressful objects linked with demanding fish farming. The digestibility of selenium from diets containing fishmeal is $46-54 \%$, which is considerably lesser than from semi-purified diets that contain organic selenium (Bell and Cowey 1989; Rider et al. 2008). Therefore, maintaining the proper salmonid cultures is necessary to add relatively more bioavailable forms of selenium in fish diets.

Complete blood profile diagnosis delivers important information which can help in the exploration and supervision of fish health (Pincus 1996; Cnaani et al. 2004; К̌Rehulka et al. 2004; Khan et al. 2016). During unfavorable conditions, the blood profile is also disturbed showing a threat to fish health. Selenium acts as a powerful antioxidant and its supplementation in fish feed can provide firmness and reliability to the red blood cells by reducing the peroxidation process and defends them from oxidative damage (rupturing) (Ong and Packer 1992). Previous researches have indicated the role of selenium in improving the hematological status of various fish species (El-Hammady et al. 2007; Molnár et al. 2011; Khan et al. 2016). The red blood cell count considerably increased in the blood of Nile tilapia fed diets containing Se than the fish fed a selenium-free diet (Molnár et al. 2011). Similarly, hematocrit value in fish blood significantly improves with the proper selenium intake while a selenium-deficient or selenium-free diet reduces the hematocrit levels (ElHammady et al. 2007).

In a recent research study regarding the supplementation of the nano form of selenium in T. putitora feed significantly increased the red blood cell count, hemoglobin content, and the hematocrit values while the selenium-free diet showed reduced red blood cell count and hemoglobin and hematocrit values (Khan et al. 2016). Le et al. (2013) stated when yellowtail kingfish was challenged with a bacterial strain; the hematocrit values were higher in fish fed selenium-added diets as compared to the fish fed the selenium-free diet. According to Gaber (2007), the hemoglobin content increased with increasing the amounts of dietary sodium 
selenite in common carp (Cyprinus carpio L.) diets. In another study, a higher red blood cell count, hemoglobin content, and hematocrit values were obtained when African catfish (Clarias gariepinus B.) fed diets containing organic selenium. The improvement in fish blood profile occurs due to an increase in the selenium levels and thus with proper dietary selenium supplementation, the fish hematological status becomes normal (Abdel-Tawwab et al. 2007).

Inadequate dietary selenium supplementation has a direct negative impact on the proliferative strength of blood lymphocytes by changing the transferrin receptors (Pighetti et al. 1998; Khan et al. 2016). According to Combs and Combs (1986), selenium is involved in the production and proliferation of antibodies and provides protection to the $\mathrm{B}$ lymphocytes through the stimulation of glutathione peroxidase activity. Seleniumsupplemented diets (either with selenium nanoparticles or selenomethionine) considerably improves the plasma and tissue glutathione peroxidase activity in crucian carp (Carassius auratus gibelio) which consequently improves the production and propagation of B lymphocytes during the unfavorable situations (Zhou et al. 2009).

The B lymphocyte cell production and propagation perform an important role in the enhancement of lysozyme activity in fish (Burk et al. 2003). The lysozyme activity is necessary for the maintenance of innate immune status of fish (Kumar et al. 2008; Khan et al. 2016). Goldfish (Carassius auratus) when treated with a sufficient selenium showed higher plasma lysozyme activity and improved production and expression of IgM antibodies which means that selenium treatment increased the immunity in goldfish (Choi et al. 2013). Similarly, Lee et al. (2009) revealed the useful effects of dietary selenium supplementation on the lysozyme activity in juvenile olive flounder (Paralichthys olivaceus). The lysozyme activity of $T$. putitora significantly increased with dietary selenium nanoparticle supplementation at the rate of $0.68 \mathrm{mg}$ nano $\mathrm{Se} \mathrm{kg}^{-1}$. Moreover, Le et al. (2013) documented a significantly higher lysozyme enzyme activity in yellowtail kingfish (Seriola lalandi) fed a diet supplemented with Se.

The non-specific immunity including the albumin and globulin levels are also usually used for assessing the effect of selenium in fish immunity (Abdel-Tawwab et al. 2007). Albumin and globulin measurements and analyses tell about the general fish nutritional and health position, the integrity of its cells, and a normal liver functioning. The low levels of albumin and globulin can disturb the normal protein synthesis and cause losses of these important proteins with feces or enlarged catabolism (Nguyen 1999). The rise in albumin and globulin concentrations with increasing organic selenium levels in fish diet may be due to the increase of their production in the liver tissue. Comparable results were acquired by Ahmad et al. (2006). Moreover, the supplementation of organic selenium resulted in higher values of glucose, total lipids, and uric acid in African catfish (AbdelTawwab et al. 2007).

Dietary selenium supplementation is associated with protein synthesis in fish and improves the total protein content in fish body (Burk and Hill 1993; Raza 2012; Jamil 2013; Khan et al. 2016). It acts as a substitution for sulfur in the protein synthesis process. It is an integral part of the selenoenzymes and thus playing an important role in the regulation of selenoproteins. The proteins that have selenium as an essential part in their polypeptide chains are called selenoproteins which are usually available in all animals including fish (Castellano et al. 2005; Khan et al. 2016). These proteins stimulate and upregulate various biological functions inside the fish body (Tinggi 2008; Jamil 2013; Khan et al. 2016). Moreover, dietary selenium also promotes the body protein content through the production of growth hormones (Evan 1976; Raza 2012; Jamil 2013; Khan et al. 2016).

Selenium plays an important role in the synthesis and expression of several types of selenoproteins, all of which are important for the maintenance of physiobiochemical health of fish (Rotruck et al. 1973). Its supplementation in fish feeds strengthens the fish immunity and provides defense to the fish body cells against oxidative stress through the stimulation, synthesis, and expression of several important selenoenzymes and selenoproteins such as glutathione peroxidase, thioredoxin reductase, and selenoprotein P. Thus, fishes that receive adequate amounts of selenium can produce sufficient amounts of selenoproteins (Burk et al. 2003; Kumar et al. 2008), while low concentrations of selenium result in low selenoproteins production and as a result the immunity drops and the fish becomes susceptible to various infections and diseases (Sritunyalucksana et al. 2011).

Selenium provides protection to fish body (1) by using the reduced glutathione, which reduces the peroxides and hydroperoxides production and helps in removing stress and stabilize the normal state (Arteel and Sies 2001; Rider et al. 2008) and (2) by the stimulation of 
selenoproteins synthesis which contribute in the elimination of the deleterious effects of the oxidative stress by stimulating and activating the fish antioxidant defense system (Tapiero et al. 2003). Raza (2012) documented that supplementation of Se significantly increased the total protein content in different tissues of juvenile T. putitora. Similarly, Jamil (2013) and Khan et al. (2016) found comparable results and reported that the supplementation of selenium nanoparticles significantly increases the total protein content in different tissues of T. putitora as compared to the fish fed the selenium-free diet.

Aerobic life has a negative impact on the animal health in terms of free radical production (reactive species oxygen) (Halliwel and Gutteridge 2007). A large production of the reactive oxygen species (ROS) causes oxidative stress through the oxidation of proteins and lipids and thus induces deleterious alterations in gene expression and modifies the cell status (Livingstone 2003). Fish when attacked by any kind of stress, increases the activities of its antioxidant enzymes. These enzyme activities include the catalase, superoxide dismutase, peroxide dismutase, glutathione peroxidase, and glutathione reductase activities (Schinina et al. 1987; Johansen 2005; Raza 2012). Selenium supplementation in fish feeds increases the innate defense system of fish, and thus, fish whenever suffer from stress results in a powerful activation of the antioxidant defense system (Patching and Gardiner 1999; Kumar et al. 2008).

Selenium is a strong antioxidant trace element and plays a substantial role in the improvement of fish defense system against the oxidative stress (Patching and Gardiner 1999; Raza 2012; Jamil 2013; Khan et al. 2016). It shows its antioxidant activity once the fish faces certain kind of stress through the activation of enzymatic activities against the lipid peroxidation and helps in the elimination of hydrogen peroxides (Kohrle et al. 2000). Its supplementation is sufficient for improving several important antioxidant enzyme activities such as catalase, glutathione reductase and glutathione peroxidase activities in liver, and superoxide dismutase activity in kidney of fish. But, to neutralize the changes that stimulated the lipid peroxidation activity in the liver and kidney tissues, the high dose of selenium is essential, and even this dose has been reported to be unsuccessful in case of a reduced glutathione reductase activity in the kidney tissue of a fish suffered from certain type of toxicity (Hamilton 2004). However, the problem related to the maximum doses of selenium is that sometimes they can affect the basal values of some oxidative stress biomarkers in fish. Therefore, a proper caution is required to clearly differentiate the basal levels of these biomarkers and the higher levels in response to lower, optimum, and higher doses of selenium because higher activities of oxidative stress indicators are also not good for fish health and can cause toxicity.

In channel catfish, the glutathione peroxidase enzyme activity was increased with increasing the concentrations of dietary selenium (Gatlin and Wilson 1984). Glutathione per oxidase activity in the liver tissue of gibel carp showed positive co-relation with the dietary selenium concentrations (Han et al. 2011). According to some researches, nano form of selenium supplementation in fish feed enhances the glutathione peroxidase activity in fish tissues (Zhou et al. 2009; Jamil 2013; Khan et al. 2016). Sunde (2001) perceived that improper selenium consumption disturbs the glutathione peroxidase activity and results in a quickly decreased cellular glutathione peroxidase activity. In a recent study, a significant increase in the liver and muscle glutathione peroxidase activity was observed when $T$. putitora fed a selenium nanoparticle-added diet than the control diet. Lin and Shiau (2005) reported that liver glutathione peroxidase activity increases in juvenile grouper (Epinephelus malabaricus) with the intake of diets containing selenium and decreases in fish by the consumption of the basal diet. Atencio et al. (2009) established that the dietary selenium supplementation in the form of sodium selenite in Nile tilapia (O. niloticus) deliberates defense against the oxidative stress and the histological injuries persuaded by the cyanobacterial cells. The supplementation of Se in the diet significantly improved the antioxidant activities (glutathione peroxidase and glutathione reductase activities) in matrinxã (Brycon cephalus) as well as considerably reduced the oxidative stress in its flesh (Monteiro et al. 2007).

\section{Selenium interaction with other trace elements and vitamins (especially vitamin $\mathbf{E}$ and $\mathrm{C}$ )}

Selenium shows additive and synergistic interaction with numerous trace elements in fish and other animals (Diplock 1976; Whanger 1981; Marier and Jaworski 1983; Sorensen 1991). Generally, some of the trace elements such as arsenic, mercury, cadmium, antimony, 
bismuth, silver, copper, tungsten, and germanium (Diplock 1976; Levander 1986; Whanger 1981; Marier and Jaworski 1983) increases the selenium toxicity; however, others like the fluorine, uranium, chromium, molybdenum, cobalt, nickel, tellurium, zinc, and vanadium have no effect on the selenium-induced toxicity (Hill 1975; Ewan 1978). Ohlendorf et al. (1993) reported on the acceptance and prospective interaction of selenium with boron, molybdenum, and arsenic from the food chain animals and plants in the areas of central California compressed by the agricultural irrigation seleniferous drain water. The data about the interaction of selenium with heavy metals is still insufficient, and thus, it is necessary to study whether any interaction between selenium and other heavy metals exists in fish.

Besides selenium interaction with trace elements, it has been well established that it has a strong nutritional interaction with vitamin E and C (NRC 2011; Khan et al. 2017). The combined supplementation of vitamin E (50 ppm) and selenium ( $0.35 \mathrm{ppm})$ showed positive interaction with each other and significantly enhanced the gain weight and feed conversion ratio in rainbow trout (Oncorhynchus mykiss). Additionally, the flesh quality was also improved than in the control group (Rodríguez and Rojas 2014). Goes et al. (2016) worked on the supplementation of selenium and vitamin $\mathrm{E}$ in diets for pacu (Piaractus mesopotamicus) and described that the supplementation of $1 \mathrm{mg} \mathrm{Se} \mathrm{kg}^{-1}$ in combination with $200 \mathrm{mg}$ vit $\mathrm{E} \mathrm{kg}^{-1}$ considerably decreased the oxidation process in the meat which led to improved maintenance performance and body incomes.

Moniruzzaman et al. (2015) reported that selenium and vitamin E supplementation shows synergistic interaction and positively improves the growth performance parameters such as the weight gain, feed conversion ratio, and specific growth rate in fish. Vitamin E more than $100 \mathrm{mg}$ vit $\mathrm{E} \mathrm{kg}^{-1}$ diet supplemented with selenium ( 2 or $4 \mathrm{mg}$ selenomethionine $\mathrm{kg}^{-1}$ diet) significantly showed positive synergistic effects. Similarly, according to El-Gamal et al. (2007), the combined supplementation of vitamin $\mathrm{C}$, vitamin $\mathrm{E}$, and selenium showed best synergistic effects on the reproductive performance (fertilization success, hatching rate, and larval and fries survival) as compared to their individual use as well as the control diet. Khan et al. (2017) reported that the combined supplementation of vitamin $\mathrm{C}$ (at the rate of $300 \mathrm{mg} \mathrm{kg}^{-1}$ ) and selenium nanoparticles (at the rate of $0.68 \mathrm{mg} \mathrm{kg}^{-1}$ ) showed strong synergistic effects and improved significantly the growth performance, hematological, biochemical, and immunological aspects of $T$. putitora.

Lee et al. (2016) conducted an experiment on the synergistic effects of dietary vitamin $\mathrm{C}$ and selenium on induced methylmercury toxicity in juvenile olive flounder (Paralichthys olivaceus) and found that fish fed diets containing $400 \mathrm{mg} \mathrm{kg}^{-1}$ vitamin $\mathrm{C}$ together with 2 and $4 \mathrm{mg} \mathrm{Se} \mathrm{kg}^{-1}$ showed significantly higher weight gain, specific growth rate, and feed efficiency, whereas fish fed diet containing vit $\mathrm{C}_{400}+\mathrm{Se}_{4} \mathrm{mg} \mathrm{kg}^{-1}$ exhibited significantly higher protein efficiency ratio than the other feeding groups. In another study, a significantly low tissue $\mathrm{Hg}$ burden was observed in fish fed diets containing $400 \mathrm{mg}$ vit $\mathrm{C} \mathrm{kg}^{-1}$ with 2 and $4 \mathrm{mg}$ $\mathrm{Se} \mathrm{kg}^{-1}$. Additionally, the $100 \%$ fish survival in the experiment indicated that the supplementation of the juvenile tilapia diets with at least $400 \mathrm{mg}$ vit $\mathrm{C}$, $\mathrm{E} \mathrm{kg}^{-1}$, and $0.4 \mathrm{mg} \mathrm{kg}^{-1}$ organic selenium contributed to the lower fish mortality. Besides the survival rate, the authors reported that the supplementation of $400 \mathrm{mg} \mathrm{kg}^{-1}$ vitamin $\mathrm{C}$ and $\mathrm{E}$ in combination with $0.4 \mathrm{mg} \mathrm{kg}^{-1}$ organic selenium significantly increased the weight gain, length gain, and feed conversion ratio in tilapia fillet (Fonseca et al. 2013). Kim et al. (2003) also found $100 \%$ survival of tilapia fingerlings fed $150 \mathrm{mg} \mathrm{kg}^{-1}$ vitamin $\mathrm{C}, 100 \mathrm{mg} \mathrm{kg}^{-1}$ vitamin $\mathrm{E}$, and $0.2 \mathrm{mg} \mathrm{kg}^{-1}$ inorganic selenium. Similarly, evaluating the inclusion of selenium and vitamin $\mathrm{E}$ for a decapod crustacean (Macrobrachium amazonicum), Sampaio et al. (2004) found that the supplementation of $200 \mathrm{mg} \mathrm{kg}^{-1}$ vitamin $\mathrm{E}$ with $0.5 \mathrm{mg} \mathrm{kg}^{-1}$ selenium in the fish diet maximized the fish weight gain. According to Khan et al. (2017), the supplementation of $0.68 \mathrm{mg}$ nano $\mathrm{Se} \mathrm{kg}^{-1}$ in combination with $300 \mathrm{mg}$ vit $\mathrm{C} \mathrm{kg}^{-1}$ maintained $100 \%$ survival rate in juvenile T. putitora.

\section{Final remarks and future considerations}

Overview of the ongoing research studies regarding the selenium research in fish has highlighted clearly the importance of selenium supplementation in fish feeds and its beneficial impact on the growth as well as fish physiological health. Most of the earlier selenium research in fish has been carried out with its inorganic form, but now, we already know that the natural form of selenium is very different from its inorganic form as it more easily integrates into fish body. Some studies have reported that organic form is more bioavailable to fish 
and its supplementation shows more intestinal absorption and therefore shows more positive effects in the fish growth and physiological health than the inorganic form. However, recently some researchers have introduced the nano form of selenium into the area of selenium research and obtained better bioavailability and positive effects in fish growth and health. Therefore, all of the earlier and present literature about the selenium research clarifies the fact that still much struggle is needed to clearly differentiate the more bioavailable and less toxic forms of selenium for different fish species.

Selenium is a trace element which is required for fish in a narrow range, if it exceeds this range, it becomes toxic to fish. The main problem regarding selenium toxicity is that the levels determined during stressful conditions are usually higher and the use of such higher levels of Se during normal conditions may become toxic to fish. Thus, the differentiation of selenium for different fish species should be based on different environmental conditions such as the normal and stressful conditions. This will help in reducing the supplementation of unwanted amounts of selenium in order to control the feed costs and also to prevent the toxicity which can be produced in fish due to the supplementation of higher levels.

Many important advances in selenium status assessment and selenium requirements have been recognized on the basis of glutathione peroxidase activity, an important enzyme of the immunity and defense systems of fish. Some years ago, researchers of the animal nutrition, animal physiology, and animal immunology have started using modern approaches and tools of the proteomics and molecular biology for investigating and exploring further hiding facts about the new forms of selenoproteins which are vital for the maintenance of life processes. They succeeded up to certain level in their efforts and today sufficient information is available about different types of selenoproteins, their molecular structures, mechanisms, and protective functions in terrestrial animals especially in the mammals. However, in fish and other aquatic animals, this area is under research and still sufficient information is unavailable. Therefore, in future researches regarding the selenium research in fish and the role of selenium in fish nutrition and fish health, the use of some new approaches, tools, and recent advances (methodologies) of the modern genomics and proteomics in close association with the description and elucidation of new selenoproteins will be a driving force in reconsidering and replacing the old approaches in fish related to the selenium research with new ones.

Acknowledgements We acknowledge the Third World Academy of Sciences (TWAS), Conselho Nacional de Desenvolvimento Científico e Tecnológico (CNPq), Center of Aquaculture, São Paulo State University, Jaboticabal, SP, Brazil, and the Department of Animal Sciences, Quaid-i-Azam University Islamabad, Pakistan.

\section{References}

Abdel-Tawwab M, Mamdouh AA, Abbass MFE (2007) Growth performance and physiological response of African catfish (Clarias gariepinus B.) fed organic selenium prior to the exposure to environmental copper toxicity. Aquaculture 272:335-345

Ahmad MH, El-Marakby HI, Seden MEA, Abdel-Tawwab M, Abou-El-Atta ME (2006) The use of organic selenium (SelPlexÒ) in practical diets for Nile tilapia (Oreochromis niloticus L.): effect on growth performance, feed utilization, whole-body composition and entro-pathogenic Aeromonas hydrophila-challenge. In: Contreras W, Fitzsimmons K (eds) The 7th international symposium on tilapia in aquaculture, 6-8 September 2006. Boca del Rio, Veracruz, pp 95107

Albrecht MA, Evans CW, Raston CL (2006) Green chemistry and the health implications of nanoparticles. Green Chem 8:417432

Arteel GE, Sies H (2001) The biochemistry of selenium and the glutathione system. Environ Toxicol Pharmacol 10:153-158

Atencio L, Moreno I, Jos A', Prieto AI, Moyano R, Blanco A, Came'an AM (2009) Effects of dietary selenium on the oxidative stress and pathological changes in tilapia (Oreochromis niloticus) exposed to a microcystinproducing cyanobacterial water bloom. Toxicon 53:269-282

Baines SB, Fisher NS, Stewart R (2002) Assimilation and retention of selenium and other trace elements from crustacean food by juvenile striped bass (Morone saxitilis). Limnol Oceanogr 47: 646-655

Beckett GJ, Nicol F, Rae PWH, Beech S, Guo Y, Arthur JR (1993) Effects of combined iodine and selenium deficiency on thyroid hormone metabolism in rats. Am J Clin Nutr Suppl 57: 240S-243S

Bell GJ, Cowey CB (1989) Digestibility and bioavailability of dietary selenium from fishmeal, selenite, selenomethionine and selenocysteine in Atlantic salmon (Salmo salar). Aquaculture 81:61-68

Bell JG, Cowey CB, Adron JW, Pirie BJS (1987) Some effects of selenium deficiency on enzyme activities and indices of tissue peroxidation in Atlantic salmon parr (Salmo salar). Aquaculture 65:43-54

Bell JG, Cowey CB, Adron JW, Shanks AM (1985) Some effects of vitamin $\mathrm{E}$ and selenium deprivation on tissue enzyme 
levels and indices of tissue peroxidation in rainbow trout (Salmo gairdneri). Br J Nutr 53:149-157

Bell JG, Pirie BJS, Adron JW, Cowey CB (1986) Some effects of selenium deficiency on glutathione peroxidase (EC 1.11.1.9) activity and tissue pathology in rainbow trout (Salmo gairdneri). Br J Nutr 55:305-311

Brigelius-Flohé R (1999) Tissue-specific functions of individual glutathione peroxidases. Free Radic Biol Med 27:951-965

Brown KM, Arthur JR (2001) Selenium, selenoproteins and human health: a review. Public Health Nutr 4(2B):593-599

Burk RF, Hill KE, Motley AK (2003) Selenoprotein metabolism and function: evidence for more than one function for selenoprotein. J Nutr 133:1517S-1520S

Burk RF (1976) Selenium in man. In: Prasad AS (ed) Trace elements in human health and disease. Academic Press, London, pp 105-134

Burk RF, Hill KE (1993) Regulation of selenoproteins. Annu Rev Nutr 13:65-81

Castellano S, Lobanov AV, Chapple C, Novoselov SV, Albrecht M, Hua D, Lescure A, Lengauer T, Krol A, Gladyshev VN, Guigó R (2005) Diversity and functional plasticity of eukaryotic selenoproteins: identification and characterization of the SelJ family. P Natl Acad Sci USA 102:16188-16193

Chien LC, Yeh CY, Huang SH, Shieh MJ, Han BC (2003) Pharmacokinetic model of daily selenium intake from contaminated seafood in Taiwan. Sci Total Environ 311:57-64

Choi YJ, Kim NN, Shin HS, Park MS, Kil GS, Choi CY (2013) Effects of waterborne selenium exposure on the antioxidant and immunological activity in the goldfish (Carassius auratus). Mol Cell Toxicol 9:365-373

Clark RF, Strukle E, Williams SR, Manoguerra AS (1996) Selenium poisoning from a nutritional supplement. J Am Med Assoc 275:1087-1088

Cnaani A, Tinman S, Avidar Y, Ron M, Hulata G (2004) Comparative study of biochemical parameters in response to stress in Oreochromis aureus, $O$ mossambicus and two strains of $O$ niloticus. Aquacult Res 35:1434-1440

Collipp PJ, Kelemen J, Chen SY, Castro-Magana M, Angulo M, Derenoncourt A (1984) Growth hormone inhibition causes increased selenium levels in Duchenne muscular dystrophy: a possible new approach to therapy. J Med Genet 21:254-256

Combs GFJ, Combs SB (1986) The role of selenium in nutrition. Academic Press. Harcourt Press Jovanovich Publishers, Orlando San Diego New York Austin, Toronto, pp 1-527

Cotter PA, Craig SR, Mclean E (2008) Hyper accumulation of selenium in hybrid striped bass: a functional food for aquaculture? Aquac Nutr 14:215-222

Diplock AT (1976) Metabolic aspects of selenium action and toxicity. CRC Crit Rev Toxicol 4:271-329

Eisler R (2000) Selenium handbook of chemical risk assessment: health hazards to humans, plants, and animals, vol. 3. Lewis Publishers, CRC press, Boca Raton, pp 1649-1705

Elia AC, Prearob M, Pacinia N, Dörra AJM, Abete MC (2011) Effects of selenium diets on growth, accumulation and antioxidant response in juvenile carp. Ecotoxicol Environ Saf 74: $166-173$

EL-Gamal AHE, EL-Greisy ZA, EL-Ebiary EH (2007) Sinergistic effects of vitamins $\mathrm{C}$ and $\mathrm{E}$ and selenium on the reproductive performance of Nile tilapia (Oreochromis niloticus). J Appl Sci Res 3(7):564-573
El-Hammady AKI, Ibrahim SA, El-Kasheif MA (2007) Synergistic reactions between vitamin E and selenium in diets of hybrid tilapia (Oreochromis niloticus $\times$ Oreochromis aureus) and their effect on the growth and liver histological structure. Egypt J Aquat Biol Fish 11:53-58

Ewan RC (1976) Effect of selenium on rat growth, growth hormone and diet utilization. J Nutr 106:702-709

Ewan RC (1978) Toxicology and adverse effects of mineral imbalance with emphasis on selenium and other minerals. In: Oehme FW (ed) Toxicity of heavy metals in the environment, part 1. Marcel Dekker, New York, pp 445-489

Farchi-Pisanty O, Hackett JPB, Moav B (1995) Regulation of fish growth hormone transcription. Mol Mar Biol Biotechnol 4: 215-223

Fairweather-Tait SJ, Collings R, Hurst R (2010) Selenium bioavailability: current knowledge and future research requirements. Am J Clin Nutr 91:1484S-1491S

Felton SP, Landolt ML, Grace R (1996) Effects of selenium dietary enhancement on hatchery-reared coho salmon (Oncorhynchus kisutch Walbaum), when compared to wild coho: hepatic enzymes and seawater adaptation evaluated. Aquac Res 27:135-142

Felton SP, Smith LS, Ji W, Halver JE (1989) Implications of selenium involvement during chemical and physical stress in salmonids. Proc Soc Exp Biol Med, Society for Experimental Biology and Medicine Northwest Section meeting, Pullman, WA (USA), 29 Oct 1988, pp 190-303

Fjoelstad M, Heyeraas AL (1985) Muscular and myocardial degeneration in cultured Atlantic salmon, Salmo salar L., suffering from 'Hitra disease'. J Fish Dis 8:367-372

Fonseca SBD, Silva JHVD, Filho EMB, Mendes PDP, Fernandes JBK, Amancio ALL, Filho JJ, Lacerda PBD, Silva FRPD (2013) Influence of levels and forms of selenium associated with levels of vitamins $\mathrm{C}$ and $\mathrm{E}$ on the performance, yield and composition of tilapia fillet. Food Sci Technol (Campinas). vol. 33 supl. 1 Campinas. http://dx.doi.org/10.1590/S010120612013000500017

Gaber MM (2007) Efficiency of selenium ion inclusion into common carp (Cyprinus carpio L.) diets. J Fish Int 2(3):250-254

Ganther HG (1978) Modification of methylmercury toxicity and metabolism by selenium and vitamin E: possible mechanisms. Environ Health Perspect 25:71-76

Gasmi A, Garnier R, Galliot-Guilley M, Gaudillat C, Quartenoud B, Buisine A, Djebbar D (1997) Acute selenium poisoning. Vet Hum Toxicol 39:304-308

Gatlin DM III, Wilson RP (1984) Dietary selenium requirement of fingerling channel catfish. J Nutr 114:627-633

Gatlin DM III, Poe WE, Wilson RP (1986) Effects of singular and combined dietary deficiencies of selenium and vitamin $\mathrm{E}$ on fingerling channel catfish. J Nutr 116:1061-1067

Goes ESDR, Feiden A, Boscolo WR, Goes MD, Signor A (2016) Supplementation of selenium and vitamin $\mathrm{E}$ in diets for pacu (Piaractus mesopotamicus): effect on performance, body yields and lipid stability. Afr J Agric Res 11(2):65-73

Halliwell B, Gutteridge JMC (2007) Free radicals in biology and medicine, 4th edn. Clarendon Oxford University Press

Hamilton SJ (2003) Review of residue-based selenium toxicity thresholds for freshwater fish. Ecotoxicol Environ Saf 56: 201-210 
Hamilton SJ (2004) Review of selenium toxicity in the aquatic food chain. Sci Total Environ 326:1-31

Hamilton SJ, Buhl KJ, Faerber NL (1990) Toxicity of organic selenium in the diet to Chinook salmon. Environ Toxicol Chem 9:347-358

Hamre K, Mollan TA, Sæle Ø, Erstad B (2008) Rotifers enriched with iodine and selenium increase survival in Atlantic cod (Gadus morhua) larvae. Aquaculture 284:190-195

Han D, Xie S, Liu M, Xiao X, Liu H, Zhu X, Yang Y (2011) The effects of dietary selenium on growth performances, oxidative stress and tissue selenium concentration of gibel carp (Carassius auratus gibelio). Aquac Nutr 17:741-749

Hicks DB, Hilton JW, Ferguson HW (1984) Influence of dietary selenium on the occurrence of nephrocalcinosis in the rainbow trout (Salmo gairdneri Richardson). J Fish Dis 7:379389

Hilton JW, Hodson PV, Slinger SJ (1980) The requirement and toxicity of selenium in rainbow trout (Salmo gairdneri). $\mathrm{J}$ Nutr 110:2527-2535

Hill CH (1975) Interrelationships of selenium with other trace elements. Fed Am Soc Exp Biol 34:2096-2100

Hodson PV, Hilton JW (1983) The nutritional requirements and toxicity to fish of dietary and waterborne selenium. Ecol Bull 35:335-340

Hsu PC, Guo YL (2002) Antioxidant nutrients and lead toxicity. Toxicology 180:33-44

Jamil Z (2013). Effects of inorganic and nanoform of selenium on growth performance and biochemical indices of mahseer (Tor putitora). M.Phil. Thesis, Quaid-i-Azam University, Islamabad, Pakistan

Janz DM (2011) Selenium. In: Wood CW, Farrell AP, Brauner CJ (eds) homeostasis and toxicology of essential metals. Fish physiology Vol 31A. Elsevier, San Diego, pp 327-374

Janz DM, DeForest DK, Brooks ML, Chapman PM, Gilron G, Hoff D, Hopkins WD, McIntyre DO, Mebane CA, Palace VP, Skorupa JP, Wayland M (2010) Selenium toxicity to aquatic organisms. In: Chapman PM, Adams WJ, Brooks ML, Delos CG, Luoma SN, Maher WA, Ohlendorf HM, Presser TS, Shaw DP (eds) Ecological assessment of selenium in the aquatic environment. CRC Press, Boca Raton, pp $141-231$

Johansen SH (2005) Selenium study on endangered razorback sucker is flawed. Ecotoxicol Environ Saf 61:313-326

Jovanovic A, Grubor-Lajsic G, Djukic N, Gardinovacki G, Matic A, Spasic M (1997) The effect of selenium on antioxidant system in erythrocytes and liver of the carp (Cyprinus carpio L). Crit Rev Food Sci 37(5):443-448

Julshamn K, Sandnes K, Lie O, Waagbo R (1990) Effects of dietary selenium supplementation on growth, blood chemistry and trace element levels in serum and liver of adult Atlantic salmon (Salmo salar). Fisk Dir Skr Ernaering III 2: $47-58$

Juniper DT, Phipps RH, Ramos-Morales E, Bertin G (2008) Effect of dietary supplementation with selenium-enriched yeast or sodium selenite on selenium tissue distribution and meat quality in beef cattle. J Anim Sci 86:3100-3109

Khan KU, Zuberi A, Nazir S, Fernandes JBK, Jamil Z, Sarwar H (2016) Effects of dietary selenium nanoparticles on physiological and biochemical aspects of juvenile Tor putitora. Turk J Zoo 40:704-712
Khan KU, Zuberi A, Nazir S, Ullah I, Jamil Z, Sarwar H (2017) Synergistic effects of dietary nano selenium and vitamin $C$ on growth, feeding, and physiological parameters of mahseer fish (Tor putitora). Aquac Rep 5:70-75

Kim K, Wang X, Choi S, Park G, Koo J, Bai SC (2003) No synergistic effects by the dietary supplementation of ascorbic acid, a-tocopheryl acetate and selenium on the growth performance and challenge test of Edwardsiella tarda in fingerling Nile tilapia (Oreochromis niloticus L). Aquacult Res 34: 1053-1058.

Klasing KC (1998) Comparative avian nutrition. Oxford University Press, NewYork, p 360

Kleinow KM, Brooks AS (1986) Selenium compounds in the fathead minnow (Pimephales promelas)- I. Uptake, distribution, and elimination of orally administered selenate, selenite, and Lselenomethionine. Comp Biochem Pharmacol 83C:61-69

Kohrle J, Brigelius-Flohe R, Bock A (2000) Selenium in biology: facts and medical perspectives. Biol Chem 381:849-864

Kohrle J, Gartner R (2009) Selenium and thyroid. Best Pract Res Clin Endocrinol Metab 23:815-827

Kumar N, Garg AK, Mudgal V (2008) Effect of different levels of selenium supplementation on growth rate, nutrient utilization, blood metabolic profile, and immune response in lambs. Biol Trace Elem Res 126:S44-S56. doi:10.1007/s12011008-8214-8

Kucukbay FZ, Yazlak H, Karaca I, Sahin N, Tuzcu M, Cakmac M, Sahin K (2009) The effects of dietary organic or inorganic selenium in rainbow trout (Oncorhynchus mykiss) under crowding conditions. Aquac Nutr 15:569-576

Lall S (2000) Nutrition and health of fish. In: Cruz-Sua'rez L, Ricque-Marie D, Tapia- Salazar M, Olvera-Novoa M, Civera-Cerecedo R (eds), Avances en Nutricio'n Acul'cola V. Memorias del V Simposium Internacional de Nutricio'n Acuı'cola. Me' rida, Yucata'n, Mexico, 19-22 November 2000, pp 13-23

Le KT, Fotedar R, Partridge G (2013) Selenium and vitamin E interaction in the nutrition of yellowtail kingfish (Seriola lalandi): physiological and immune responses. Aquac Nutr 20:303-313

Lee S, Park G, Moniruzzaman M, Bae J, Song Y, Kim K, Bai SC (2016) Synergistic effects of dietary vitamin $C$ and selenium on induced methylmercury toxicity in juvenile olive flounder (Paralichthys olivaceus). Turk J Fish Aquat Sci. doi:10.4194 /1303-2712-v17_3_09 (in press)

Lee JH, Kim YC, Park SL, Bai SC (2009) Evaluation of the optimum dietary selenium (Se) level to improve immune responses in juvenile olive flounder (Paralichthys olivaceus). J Korean Fish Soc 42:26-33

Lemly D (1997) A teratogenic deformity index for evaluating impacts of selenium on fish populations. Ecotoxicol Environ Safe 37:259-266

Lemly D (2002) Symptoms and implications of selenium toxicity in fish: the Belews Lake case example. Aquat Toxicol 57:3949

Levander OA (1986) Selenium. In: Mertz W (ed) Trace elements in human and animal nutrition. Academic Press, London, pp 139-197

Li H-F, McGrath SP, Zhao F-J (2008) Selenium uptake, translocation and speciation in wheat supplied with selenate or selenite. New Phytol 178:92-102 
Lin YH, Shiau SY (2003) Dietary lipid requirement of grouper (Epinephelus malabaricus), and effects on immune responses. Aquaculture 225:243-250

Lin Y, Shiau S (2005) Dietary selenium requirements of juvenile grouper (Epinephelus malabaricus). Aquaculture 250:356363

Lin Y (2014) Effects of dietary organic and inorganic selenium on the growth, selenium concentration and meat quality of juvenile grouper (Epinephelus malabaricus). Aquaculture 430: 114-119

Liu K, Wang X, Ai Q, Mai K, Zhang W (2010) Dietary selenium requirement for juvenile cobia (Rachycentron canadum $L$ ). Aquacult Res 41:594-601

Liu Y, Feng L, Zhao B, Zhou X (2012) Effects of nucleotides and organic selenium supplementation on growth and digestive ability of juvenile Jian carp (Cyprinus carpio var. Jian) in diets with partial substitution of fish meal by soybean meal. J Sichuan Agric Univ 2:238-242 (In Chinese)

Livingstone DR (2003) Oxidative stress in aquatic organism in relation to pollution and agriculture. Rev Med Vet 154:427430

Lorentzen M, Maage A, Julshamn K (1994) Effects of dietary selenite or selenomethionine on tissue selenium levels of Atlantic salmon (Salmo salar). Aquaculture 121:359-367

Maage A, Julshamn K, Ulgenes Y (1991) A comparison of tissue levels of four essential trace elements in wild and farmed Atlantic salmon (Salmo salar). Fisk Dir Skr Ernaering IV(2): $111-116$

Mahan DC (1999) Organic selenium: using nature's model to redefine selenium supplementation for animals. In: Lyons TP, Jacques KA (eds) biotechnology in the feed industry. Proceedings of the 15th annual symposium. Nottingham University press, Nottingham, pp 523-535

Mahan DC, Cline TR, Richert B (1999) Effects of dietary levels of selenium-enriched yeast and sodium selenite as selenium sources fed to growing-finishing pigs on carcass characteristics, and loin quality. J Anim Sci 77:2172-2179

Mahan DC, Parrett NA (1996) Evaluating the efficacy of selenium-enriched yeast and sodium selenite on tissue selenium retention and serum glutathione peroxidase activity in grower and finisher swine. J Anim Sci 74:2967-2974

Marier JR, Jaworski JF (1983) Interactions of selenium. National Research Council Canada report no. 20643, Ottawa, Canada

Mateo RD, Spallholz JE, Elder R, Yoon I, Kim SW (2007) Efficacy of dietary selenium sources on growth and carcass characteristics of growing-finishing pig fed diets containing high endogenous selenium. J Anim Sci 85:1177-1183

Meinhold H, Campos-Barros A, Walzog B, Köhler R, Müller R, Behne D (1993) Effects of iodine deficiency on type I, type II and type III iodothyronine deiodinases and circulating thyroid hormones in the rat. Exp Clin Endocrinol 101:87-93

Moav B, McKeown BA (1992) Thyroid hormone increases transcription of growth hormone mRNA in rainbow trout pituitary. Horm Metab Res 24(1):10-14

Molnár T, Biró J, Balogh K, Mézes M, Hancz C (2011) Improving the nutritional value of Nile tilapia fillet by dietary selenium supplementation. Isr J Aquacult Bamidgeh 63(744):9

Moniruzzaman M, Park G, Yun H, Lee S, Park Y, Bai SC (2015) Synergistic effects of dietary vitamin $\mathrm{E}$ and selenomethionine on growth performance and tissue methyl mercury accumulation on mercury induced toxicity in juvenile olive flounder
(Paralichthys olivaceus) (Temminck et Schlegel). Aquacult Res 1-11 doi: 10.1111/are.12904

Monteiro DA, Rantin FT, Kalinin AL (2009) The effects of selenium on oxidative stress biomarkers in the freshwater characid fish matrinxã (Brycon cephalus) (Günther, 1869) exposed to organophosphate insecticide Folisuper 600 BR ${ }^{\circledR}$ (methyl parathion). Comp Biochem Physiol C 149:40-49

Mousa MA (2004) The effect of thyroxin on the activity of activin bA during the growth of the larvae of the Nile tilapia (Oreochromis niloticus). J Union Arab Biol Cairo 22(A) Zool):99-120

Muller EE, Locatelli V, Cocchi VD (1999) Neuroendocrine control of growth hormone secretion. Physiol Rev 79:511-607

National Research Council (NRC) (2011) Nutrient Requirements of Fish and Prawn. National Academies Press, Washington, DC, USA, pp. 207-209

Nguyen HT (1999) Transport proteins. In: Loeb WF, Quimby FW (eds) the clinical chemistry of laboratory animals, Second edn. Taylor and Francis, Philadelphia, pp 309-335

Nugroho RA, Fotedar R (2013) Dietary organic selenium improves growth, survival and resistance to Vibrio mimicus in cultured marron (Cherax cainii) (Austin, 2002). Fish Shellfish Immunol 35:79-85

Ogle RS, Knight AW (1989) Effects of elemental foodborne selenium on growth and reproduction of the fathead minnow (Pimephales promelas). Arch Environ Contam Toxicol 18: 795-803

Ohlendorf HM, Skorupa JP, Saiki MK, Barnum DA (1993) Food chain transfer of trace elements to wildlife. In: Allen RG (ed) Management of irrigation and drainage systems: integrated perspectives. American Society of Civil Engineers, New York, pp 596-603

Ong ASH, Packer L (1992) Molecular and cell biology updates. Lipid-soluble antioxidants: biochemistry and clinical applications. Basel: Birkhäuser. ISBN: 978-3-0348-7434-2 (print) 978-3-0348-7432-8 (online)

Pacitti D, Lawan MM, Sweetman J, Martin SAM, Feldmann J, Secombes CJ (2015) Selenium supplementation in fish: a combined chemical and biomolecular study to understand Sel-Plex assimilation and impact on selenoproteome expression in rainbow trout (Oncorhynchus mykiss). PLoS One 10(5):e0127041. doi:10.1371/ journal.pone.0127041

Pappas AC, Zoidis E (2012) The role of selenium in chicken physiology: new insights. In: Kapur I, Mehra A (eds) chickens: physiology, diseases, and farming practices. Nova Science Publishers, New York. ISBN-13: 9781620810279, p 167

Patching SG, Gardiner PHE (1999) Recent developments in Se metabolism and chemical speciation: a review. J Trace Elem Med Biol 13:193-214

Pincus MR (1996) Interpreting laboratory results: reference values and decision making. In: Henry JB (ed) Clinical diagnosis and management by laboratory methods, 19th edn. Saunders WB, Philadelphia, pp 74-91

Poppe T, Hastien T, Froslie A, Norheim G, Heum M (1985) Vitamin E, selenium, copper, and zinc in Atlantic salmon (Salmo salar): comparative studies of wild and farmed fish. Bull Eur Assn Fish 5(2):28

Poppe TT, Hastein T, Froeslie A, Koppanz N, Norheim G (1986) Nutritional aspects of haemorrhagic syndrome ('Hitra 
disease') in farmed Atlantic salmon (Salmo salar). Dis Aquat Organisms 1:155-162

Poston HA, Combs GF (1979) Interrelationships between requirements for dietary selenium, vitamin E, and L-ascorbic acid by Atlantic salmon (Salmo salor) fed a semi purified diet. Fish Health News 8(4):6-7

Poston HA, Combs GF, Leibovitz L (1976) Vitamin E and selenium interrelations in the diet of Atlantic salmon (Salmo salar): gross, histological and biochemical signs. J Nutr 106:892904

Pighetti GM, Eskew ML, Reddy CC, Sordillo LM (1998) Selenium and vitamin E deficiency impair transferrin receptor internalization but not IL-2, IL-2 receptor, or transferrin receptor expression. J Leuk Biol 63:131-137

Raza A (2012) Effects of graded levels of dietary selenium supplementation on the growth of juvenile mahseer (Tor putitora). M.Phil. Thesis, Quaid-i-Azam University, Islamabad Pakistan

Rayman MP (2012) Selenium and human health. Lancet 379: $1256-1268$

Rayman MP (2000) The importance of selenium to human health. Lancet 356:233-241

Reddy CC, Massaro EJ (1983) Biochemistry of selenium: a brief overview. Fundam Appl Toxicol 3(5):431-436

Řehulka J, Minařík B, Řehulková E (2004) Red blood cell indices of rainbow trout (Oncorhynchus mykiss Walbaum) in aquaculture. Aquac Res 35:529-546

Reilly C (2006) Selenium in food and health, 2nd edn. Springer, New York. PP XVI, 206. doi:10.1007/978-0-387-33244-4

Rodríguez PH, Rojas MS (2014) Efecto de dietas enriquecidas con vitamina e y selenio orgánico en el comportamiento productivo y calidad funcional del filete de trucha arco iris (Oncorhynchus mykiss). Rev Inv Vet Perú 25(2):213-225

Rider SA, Davies SJ, Jha AN, Clough R, Sweetman JW (2008) Bioavailability of co-supplemented organic and inorganic zinc and selenium sources in a white fishmeal based rainbow trout (Oncorhynchus mykiss) diet. J Anim Physiol An N (In press)

Rotruck JT, Pope AL, Ganther HE, Swanson AB, Hafeman DG, Hoekstra WG (1973) Selenium: biochemical role as a component of glutathione peroxidase. Science 179:585-590

Sandstrom B (2001) Micronutrient interactions: effects on absorption and bioavailability. Br J Nutr 85(suppl. 2):S181-S185

Sampaio FG, Kleemann GK, Sá MVDCE, Pereira ADS, Barros MM, Pezzato LE (2004) Níveis de vitamina E e de selênio para pós-larvas de Macrobrachium amazonicum. Acta Sci Anim Sci 26(1):129-135

Sarada SKS, Sairam M, Dipti P, Anju B, Pauline T, Kain AK, Sharma SK, Bagawat S, Ilavazhagan G, Kumar D (2002) Role of selenium in reducing hypoxia-induced oxidative stress: an in vivo study. Biomed Pharmacother 56:173-178

Schrauzer GN (2003) The nutritional significance, metabolism, and toxicology of selenomethionine. Adv Food Nutr Res 47: 73-112

Schrauzer GN (2006) Selenium yeast: composition, quality, analysis, and safety. Pure Appl Chem 78:105-109

Schinina ME, Maffey L, Barra D, Bossa F, Puget K, Michelson AM (1987) The primary structure of iron superoxide dismutase from Escherichia coli. FEBS Lett 221:87-90
Sorensen EMB (1986) The effects of selenium on freshwater teleosts. In: Hodgson E (ed) Rev Environ Toxicol 2. Elsevier, New York, pp 59-116

Sorensen EMB (1991) Metal poisoning in fish. CRC Press, Boca Raton

Sphallholz JE (1997) Free radical generation by selenium compounds and their pro-oxidant toxicity. Biomed Environ Sci 10(2-3):260-270

Sritunyalucksana K, Intaraprasong A, Sa-nguanrut P, Filer K, Fegan DF (2011) Organic selenium supplementation promotes shrimp growth and disease resistance to Taura syndrome virus. ScienceAsia 37:24-30

Stewart MJ, Spallholz JE, Neldner KH, Pence BC (1999) Selenium compounds have disparate abilities to impose oxidative stress and induce apoptosis. Free Radic Biol Med 26(1-2):42-48

Sunde RA (1984) The biochemistry of selenoproteins. J Am Oil Chem Soc 61:1891-1900

Surai PF (2006) Selenium in nutrition and health. Nottingham University Press, Nottingham, pp 974-974

Tanguy S, Boucher F, Besse S, Ducros V, Favier A, de Leiris J (1998) Trace elements and cardio protection: increasing endogenous glutathione peroxidase activity by oral selenium supplementation in rats limits reperfusion-induced arrhythmias. J Trace Elem Med Biol 12:28-38

Tapiero H, Townsend DM, Tew KD (2003) The antioxidant role of selenium and seleno-compounds. J Pharm Biomed Anal 57: 134-144

Tashjian DH, The SJ, Sogomonyan A, Hung SSO (2006) Bioaccumulation and chronic toxicity of dietary 1selenomethionine in juvenile white sturgeon (Acipenser transmontanus). Aquat Toxicol 79:401-409

The SJ, Deng X, Deng DF, The FC, Hung SSO, Fan TWM, Liu J, Higashi RM (2004) Chronic effects of dietary selenium on juvenile sacramento splittail (Pogonichthys macrolepidotus). Environ Sci Technol 38:6085-6093

Thomas JK, Janz DM (2011) Dietary selenomethionine exposure in adult zebrafish alters swimming performance, energetics and the physiological stress response. Aquat Toxicol 102:7986

Tinggi U (2008) Selenium: its role as antioxidant in human health. Environ Health Prevent Med 13:102-108

Todorovic M, Jovanovic M, Jokic Z, Hristov S, Davidovic V (2004) Alterations in liver and kidneys of chickens fed with high levels of sodium selenite or selenized yeast. Acta VetBeograd 54(2-3):191-200

Toufektsian MC, Boucher F, Pucheu S, Tanguy S, Ribuot C, Sanou D, Tresallet N, de Leiris J (2000) Effects of selenium deficiency on the response of cardiac tissue to ischemia and reperfusion. Toxicology 148:125-132

Underwood EJ (1977) Zinc, trace elements in human nutrition, 4th edn. Academic Press, New York, pp 196-242

Valcavi R, Zini M, Portioli I (1992) Thyroid hormones and growth hormone secretion. J Endocrinol Investig 15:313-330

Vignola G, Lambertini L, Mazzone G, Giammarco M, Tassinari M, Martelli G, Bertin G (2008) Effects of selenium source and level of supplementation on the performance and meat quality of lambs. Meat Sci 81:678-685

Wang AL, Wang WN, Liu CQ, Wang SA, Wang RD, Ma ZQ (1994) Effects of selenium concentrations in feed on the 
growth and selenium contents of Penaeus chinensis. J Fish China 18(3):245-280

Wang C, Lovell RT (1997) Organic seleniumsources, selenomethionine and selenoyeast, has higher bioavailability than an inorganic selenium source, sodium selenite, in diets for channel catfish (Ictalurus punctatus). Aquaculture 152: 223-234

Wang HL, Zhang JS, Yu HQ (2007) Elemental selenium at nano size possesses lower toxicity without compromising the fundamental effect on selenoenzymes: comparison with selenomethionine in mice. Free Radic Biol Med 42:1524 1533

Watanabe T, Kiron V, Datoh S (1997) Trace minerals in fish nutrition. Aquaculture 151:185-207

Whanger PD (1981) Selenium and heavy metal toxicity. In: Spallholz JE, Martin JL, Ganther HE (eds) Selenium in biology and medicine. AVI Publishing, Westport CT, pp 230-255

WHO (World Health Organization) (1987) Environmental health criterion 58-selenium. World Health Organization, Geneva

Wiseman S, Thomas JK, Higley E, Hursky O, Pietrock M, Raine JC, Giesy JP, Janz DM, Hecker M (2011a) Chronic exposure to dietary selenomethionine increases gonadal steroidogenesis in female rainbow trout. Aquat Toxicol 105:218-226

Wiseman S, Thomas JK, McPhee L, Hursky O, Raine JC, Pietrock M, Giesy JP, Hecker M, Janz DM (2011b) Attenuation of the cortisol response to stress in female rainbow trout chronically exposed to dietary selenomethionine. Aquat Toxicol 105: 643-651
Zhang JS, Gao XY, Zhang LD, Bao YP (2001) Biological effects of a nano red elemental selenium. Bio Factors 15:27-38

Zhang JS, Wang XF, Xu TW (2008) Elemental selenium at nano size (Nano-Se) as a potential chemo preventive agent with reduced risk of selenium toxicity: comparison with $\mathrm{Se}$ methyl selenocysteine in mice. Toxicol Sci 101:22-31

Zhang JS, Wang HL, Yan XX, Zhang LD (2005) Comparison of short-term toxicity between Nano-Se and selenite in mice. Life Sci 76:1099-1109

Zhou X, Wang Y, Gu Q, Li W (2009) Effects of different dietary selenium sources (selenium nanoparticle and selenomethionine) on growth performance, muscle composition, and glutathione peroxidase enzyme activity of crucian carp (Carassius auratus gibelio). Aquaculture (In press)

Zhu Y, Chen Y, Liu Y, Yang H, Liang G, Tian L (2012) Effect of dietary selenium level on growth performance, body composition and hepatic glutathione peroxidase activities of largemouth bass (Micropterus salmoide). Aquac Res 43: $1660-1668$

Zhu L, Han D, Zhu X, Yang Y, Jin J, Liu H, Xie S (2016) Dietary selenium requirement for on-growing gibel carp (Carassius auratus gibelio var. CAS III). Aquacult Res 1-11. doi:10.1111/are.13118

Zuberbuehler CA, Messikommera RE, Arnold MM, Forrer RS, Wenk C (2006) Effects of selenium depletion and selenium repletion by choice feeding on selenium status of young and old laying hens. Physiol Behav 87:430-440 